University of Nebraska - Lincoln

DigitalCommons@University of Nebraska - Lincoln

2005

\title{
Evaluation of Ecological Risk to Populations of a Threatened Plant from an Invasive Biocontrol Insect
}

Svata M. Louda

University of Nebraska - Lincoln, slouda1@unl.edu

Tatyana A. Rand

University of Nebraska - Lincoln, tatyana.rand@ars.usda.gov

A. E. Arnett

2Unity College, Unity, Maine

A. S. McClay

Alberta Research Council

K. Shea

Pennsylvania State University,

See next page for additional authors

Follow this and additional works at: https://digitalcommons.unl.edu/bioscilouda

Part of the Ecology and Evolutionary Biology Commons

Louda, Svata M.; Rand, Tatyana A.; Arnett, A. E.; McClay, A. S.; Shea, K.; and McEachern, K., "Evaluation of Ecological Risk to Populations of a Threatened Plant from an Invasive Biocontrol Insect" (2005). Svata M. Louda Publications. 7.

https://digitalcommons.unl.edu/bioscilouda/7

This Article is brought to you for free and open access by the Papers in the Biological Sciences at DigitalCommons@University of Nebraska - Lincoln. It has been accepted for inclusion in Svata M. Louda Publications by an authorized administrator of DigitalCommons@University of Nebraska - Lincoln. 


\section{Authors}

Svata M. Louda, Tatyana A. Rand, A. E. Arnett, A. S. McClay, K. Shea, and K. McEachern 


\title{
EVALUATION OF ECOLOGICAL RISK TO POPULATIONS OF A THREATENED PLANT FROM AN INVASIVE BIOCONTROL INSECT
}

\author{
S. M. Louda,${ }^{1,6}$ T. A. Rand,${ }^{1}$ A. E. Arnett,${ }^{2}$ A. S. McClay,${ }^{3}$ K. Shea,${ }^{4}$ And A. K. McEachern ${ }^{5}$ \\ ${ }^{1}$ School of Biological Sciences, University of Nebraska, Lincoln, Nebraska 68588 USA \\ ${ }^{2}$ Unity College, Unity, Maine 04988 USA \\ ${ }^{3}$ Alberta Research Council, P.O. Bag 4000, Vegreville, Alberta T9C 1T4, Canada \\ ${ }^{4}$ Department of Biology, 208 Mueller Laboratory, Pennsylvania State University, University Park, Pennsylvania 16802 USA \\ ${ }^{5}$ U.S. Geological Survey, Biological Resources Division, Western Ecological Research Center, \\ Channel Islands Field Station, 1901 Spinnaker Drive, Ventura, California 93001 USA
}

\begin{abstract}
Controversy exists over estimation of ecological risk in biological control. At present, the risk to the rare, federally listed Pitcher's thistle (Cirsium pitcheri) in North America from Rhinocyllus conicus, a biological control weevil now feeding on many native thistles, is unknown. We hypothesized that quantification of host specificity and potential phenological overlap between insect and plant would improve assessment of the magnitude of risk. In laboratory host specificity tests, we found no significant difference in $R$. conicus feeding or oviposition preference between the rare $C$. pitcheri and the targeted exotic weed (Carduus nutans) or between $C$. pitcheri and Platte thistle (C. canescens), a closely related native North American species known to be affected by $R$. conicus. In a garden environment, $R$. conicus spontaneously found, oviposited, and developed completely on C. pitcheri. Taller plants with more flower heads were significantly more vulnerable, suggesting that the greatest impact is likely to be on individuals that generally contribute the most to recruitment and population persistence. For eight sites in two national parks over three years, the calculated period of expected R. conicus activity overlapped $99 \%$ and $78 \%$ of the flower heads initiated by $C$. pitcheri in the southern and the northern park, respectively. A demographic model suggests that population growth rate $(\lambda)$ of $C$. pitcheri will decrease from 0.9897 to 0.8686 , while time to halve the population will decrease from 66.9 to 4.9 years, under the conservative assumption that oviposition by $R$. conicus on $C$. pitcheri will occur at the same rate as on the related $C$. canescens. Calculated decreases in $\lambda$ and $t_{0.5}$ are larger if the rate of oviposition actually observed in the laboratory tests is used. These results indicate that the weevil poses a serious quantitative, demographic risk to the threatened $C$. pitcheri. The study supports the suggestion that ecological data can be used to improve the quantification of risk to native nontarget plant populations within the potential physiological host range of a biological control insect.
\end{abstract}

Key words: Cirsium pitcheri; ecological risk assessment; insect-plant interactions; nontarget effects; plant demography; rare plants; Rhinocyllus conicus.

\section{INTRODUCTION}

Increased awareness of the threat posed by invasive exotic plants to natural and agronomic ecosystems (McKnight 1993, Office of Technology Assessment 1993, 1995, Pimentel et al. 2000, National Research Council 2002, Myers and Bazely 2003) has renewed interest in the potential of classical biological control to limit exotic weed densities (Kauffman and Nechols 1992, Hokkanen and Lynch 1995, Pimentel 1995, Delfosse 2000). Classical biological control involves the introduction of exotic species, usually insects, as natural enemies of the weed (DeBach and Rosen 1991, Van Driesche and Bellows 1996). However, controversy continues over the ecological risks associated

Manuscript received 9 July 2003; revised 23 March 2004; accepted 29 March 2004; final version received 9 June 2004. Corresponding Editor: J. A. Logan.

${ }^{6}$ E-mail: Slouda@UNL.edu with such introductions (Hoddle 2004, Louda and Stiling 2004). While viewed as a "reestablishment of natural enemies" (Hoddle 2004), the process by definition involves the deliberate introduction of alien species into new communities in new environments. Quantification of the associated risks is still a scientific frontier.

Few dispute that deliberate introductions of any exotic species entail a risk (Simberloff 1981, 1992, Turner 1985, Howarth 1991). The controversy is over the magnitude of the risk and over the information needed to evaluate it (Simberloff and Stiling 1996, 1998, Frank 1998, Marohasy 1998, McFadyen 1998, Strong and Pemberton 2001, Arnett and Louda 2002, Hoddle 2004, Louda and Stiling 2004). In weed projects, where host specificity tests are now standard (McEvoy 1996, Secord and Kareiva 1996, Thomas and Willis 1998), the controversy revolves around the degree to which current protocols characterize and quantify the likely mag- 
nitude of ecological risk to native species (Gonzalez and Gilstrap 1992, Simberloff and Stiling 1996, 1998, Frank 1998, Marohasy 1998, McFadyen 1998, Louda 1999, 2000a, Schaffner 2001, Arnett and Louda 2002, Louda et al. 2003a).

A critical, unresolved issue is the degree to which the host specificity paradigm, used to predict the host range of the exotic insect, can also be used to predict the actual magnitude of the ecological risk to a native species identified as a partial, less preferred, or secondary host in the testing. The preference and performance tests that form the host specificity evaluation compare insect response to a phylogenetically centrifugal series of plant species (McEvoy 1996, Thomas and Willis 1998, Schaffner 2001). Relative performance of individuals in these tests is used to define the species' "physiological host range" (Pemberton 2000b, Louda et al. 2003b). When some feeding or oviposition occurs on native plant species in these trials, relative preference and performance have been used to infer the magnitude of the threat expected in the field, or "ecological host range" (e.g., Zwölfer and Harris 1984, McClay 1990, Blossey et al. 1994).

However, recent findings of unexpected or unexpectedly large ecological effects in the field caused by insect weed control agents (Louda et al. 1997, Callaway et al. 1999, Pearson et al. 2000, Louda and O'Brien 2002) suggest that additional criteria are needed to estimate the likely ecological host range and impact subsequent to host specificity tests that show native species are accepted as secondary hosts (Louda 1999, 2000a, Arnett and Louda 2002, Benson et al. 2003, Louda et al. 2003a, b). If risk is defined as the product of hazard and exposure (Bouskila and Blumstein 1992, Secord and Kareiva 1996), then host specificity can be viewed as one measure of potential hazard from an exotic insect. However, additional data appear necessary to quantify likely exposure, the expected intensity of interaction, and so the total risk to native species.

Parameters that influence interaction intensity of herbivores with their host plants have been proposed as additional criteria for exposure, and so the prediction of ecological host range (Louda et al. 1998, 2003a, $b$, Louda 1999, 2000b). Multiple studies of plant-insect interactions have suggested that phenological synchrony, the relative timing of development of insect and potential host plant species, can explain a large portion of the variation in insect impact on plant performance and population impacts, including for thistle-insect interactions (Goeden and Ricker 1986a, b, 1987a, $b$, Maddox et al. 1991, Louda 1998, 2000a, Herr 2000, Russell and Louda 2004; F. L. Russell and S. M. Louda, unpublished manuscript). Thus, we hypothesized that evaluation of the expected phenological synchrony, in addition to host specificity testing as a fundamental dimension of exposure and ecological host range estimation, would increase the precision of the assessment of potential ecological impact on listed species from a biological control insect, at least within the ecological time frame. The system in which we evaluated this hypothesis takes advantage of an extensive existing database (e.g., Louda 2000a, Gassmann and Louda 2001), which includes the best quantification available to date of the demographic effects of nontarget feeding by a biological weed control agent.

This study had two major aims. The first aim was to quantify probable risk to the rare Pitcher's thistle (Cirsium pitcheri [Torr.] Torrey \& Gray), which is listed as federally "threatened" in the USA and "endangered" in Canada, from Rhinocyllus conicus Frölich, a weevil introduced for the biological control of exotic thistle species; this weevil has become invasive on native thistles in sand prairies of the central USA (Louda et al. 1997, 1998, Louda 1998, 2000a). To date, R. conicus has not been reported from Pitcher's thistle habitat in the intermittent sand dune ecosystem along the shores of the Great Lakes of North America (U.S. Fish and Wildlife Service 2002). However, it now occurs both north and south of these populations (Gassmann and Louda 2001). Our second aim was to evaluate the phenology hypothesis described in the paragraphs above.

Pitcher's thistle is a very close relative of Platte thistle, Cirsium canescens Nutt., a species whose densities have declined dramatically since first exposure to $R$. conicus in 1993 (Louda 2000a, Louda and Arnett 2000, Rose et al. 2005). Phylogenetic analyses suggest that the two species are sister species, with Platte thistle the likely progenitor for Pitcher's thistle (Johnson and Iltis 1963, Loveless and Hamrick 1988), and the species have striking ecological similarities (Keddy and Keddy 1984, Loveless 1984, McEachern 1992, Louda 1994). These facts led to the inference that $R$. conicus likely represents a significant new threat to Pitcher's thistle persistence if it reaches the $C$. pitcheri habitat (Louda et al. 1997). This inference was challenged since no direct evaluation had been done (Boldt 1997). Thus, our study was motivated by the lack of direct evidence and by the opportunity to evaluate the hypothesis that quantitative evaluation of ecological parameters, such as phenological synchrony, would improve the quantitative assessment of exposure and probable ecological risk to rare plant species from invasive phytophagous insects.

With these two aims in mind, we addressed five questions that focus on the critical parameters defining potential use and demographic impact of $R$. conicus on $C$. pitcheri. First, given the opportunity, does $R$. conicus recognize Pitcher's thistle as a feeding and oviposition host? "No-choice" acceptance tests are critically important in this context, since the coevolved targeted weed, Carduus nutans L., does not occur within $C$. pitcheri's protected dune habitat. Second, if $C$. pitcheri is an acceptable host, how strong are the weevil's feeding and oviposition responses to Pitcher's thistle relative to its responses to other thistles, such as its coevolved host, the targeted weed, Carduus nutans, and 
its close relative Cirsium canescens that is already being affected negatively by $R$. conicus? Third, can the weevil complete development on Pitcher's thistle plants? Fourth, what is the likely magnitude of phenological overlap between the projected $R$. conicus oviposition period with flower head availability of Pitcher's thistle within the thistle's protected habitat of two national parks in the USA? Fifth, using a simple demographic model, would the weevil's use of $C$. pitcheri suggested in laboratory and garden data have significant population-level consequences?

We used laboratory host specificity tests, garden exposure of potted $C$. pitcheri plants within the current range of North American populations of $R$. conicus in Canada, and field data on flowering phenology of $C$. pitcheri plants in their protected habitat in Indiana and Michigan, USA, and on weevil activity dates in locales to the north and south of this habitat to parameterize both the hazard and the exposure components of environmental risk. These data and demographic parameters from the literature allowed us to model the population consequences of an interaction. The host specificity tests in the laboratory and garden clearly demonstrate host recognition, colonization, feeding, oviposition, and development of $R$. conicus on Pitcher's thistle. The field data suggest a high probability of significant phenological overlap between $R$. conicus and reproductive effort of $C$. pitcheri within its protected habitat. Finally, the model predicts a significant demographic effect by $R$. conicus is likely on this threatened plant species.

\section{Natural history and background}

The flowerhead-feeding weevil, Rhinocyllus conicus, was introduced into North America from its indigenous region in Europe in July 1968 to control Eurasian Carduus spp. thistles, especially musk thistle $C$. nutans (Zwölfer and Harris 1984, Gassmann and Louda 2001). Weevils from eastern France were released in Nebraska early in the program, 1969-1972 (McCarty et al. 1981). Over-wintering adults of $R$. conicus emerge in late spring, feed, and oviposit on thistle flower heads, leaving easily observed external egg cases (Rees 1982, Zwölfer and Harris 1984). Timing of adult weevil activity in spring is best predicted by a combination of winter and spring growing degree-days and spring precipitation (Russell and Louda 2004; F. L. Russell and S. M. Louda, unpublished manuscript). Phenological synchrony between this insect and its host plant species has been hypothesized to be a key mechanism in determining relative use among thistle species by $R$. conicus, both in its indigenous environment (Zwölfer and Preiss 1983, Klein 1991) and in its nontarget host use in North America (Goeden and Ricker 1986a, b, 1987a, b, Louda 1998, Herr 2000, Russell and Louda 2004). The larvae feed for 14-30 days, destroying the receptacle, florets, and seeds within a developing flower head. After the pupal stage (14-21 days) and a qui- escent period (7-14 days) within distinctive chambers within the flower head, new adults emerge and disperse to over-wintering sites.

In $1993, R$. conicus invaded well-studied prairie grasslands in the Sand Hills of central Nebraska, USA (Louda et al. 1997, Louda 2000a), in sites without the targeted exotic thistles (Lamp and McCarty 1981, Louda et al. 1990). Weevil numbers in the flower heads of Platte thistle (C. canescens) increased exponentially over three years (Louda 1998) and have remained high, reducing seed production by $86 \%$ (Louda $2000 a$, Louda and Arnett 2000, Louda et al. 2003a). Since 1993, population density of Platte thistle in demography plots has declined over $80 \%$ (Louda and Arnett 2000, Louda et al. 2003a). Demography plot data and integral projection model methods (Easterling et al. 2000, Rees and Rose 2002) demonstrate that the decline of Platte thistle ( $C$. canescens) is related to this invasion. Our model predicts significant long-term demographic effects for Platte thistle (Rose et al. 2005), consistent with experimental evidence demonstrating the significant effect of native floral herbivores on density and lifetime maternal fitness of this native thistle (Louda et al. 1990, 1992, Louda and Potvin 1995).

The rare Pitcher's thistle (Cirsium pitcheri) is a state and federally listed "threatened" species in the USA (U.S. Fish and Wildlife Service 2002) and an "endangered" species in Canada (Environment Canada, Schedule 1: List of species at risk, available online). ${ }^{7}$ This species is restricted to the intermittent coastal sand dune ecosystem around the Great Lakes of North America (Keddy and Keddy 1984, Loveless 1984, McEachern 1992, U.S. Fish and Wildlife Service 2002). Similarities between Pitcher's thistle and its close congener Platte thistle include life history; both are longlived, monocarpic perennials with determinant flowering. Juvenile rosettes of both species persist 2-11 years (McEachern 1992, Louda and Potvin 1995; S. M. Louda, unpublished data). Both initiate reproductive development early, in May (Lamp and McCarty 1981, Loveless 1984), and have similarly sized flower heads. Most plants release seed in mid-summer: Platte thistle by July (Louda and Potvin 1995) and Pitcher's thistle by August (Loveless 1984). Floral herbivory by native insects can be extensive on both species (Keddy and Keddy 1984, Loveless 1984, Louda and Potvin 1995, Bevill et al. 1999), and seed limits seedling recruitment for both species (Louda et al. 1990, Louda and McEachern 1995, Louda and Potvin 1995; S. M. Louda and A. K. McEachern, unpublished data).

\section{Methods}

\section{Laboratory tests of host recognition and preference}

We evaluated host recognition, feeding acceptance, and oviposition preference of Rhinocyllus conicus for

\footnotetext{
$7\langle$ http://www.sararegistry.gc.ca/species/schedules_e. $\operatorname{cfm} ? \mathrm{id}=1\rangle$
} 
Pitcher's thistle in the laboratory at Cedar Point Biological Station in Ogallala, Nebraska (NE), using contemporary protocols for evaluation of host specificity (McClay 1990, McEvoy 1996). These tests paralleled our evaluation of the acceptance and preference of $R$. conicus for Platte thistle (Cirsium canescens) relative to the targeted exotic musk thistle (Arnett and Louda 2002). Sample size for some tests with $C$. pitcheri necessarily was limited by its threatened status. However, the tests were repeated in two years and the results were consistent (see Results).

In each year $(1999,2000)$, we collected 30 inflorescence branches, each with a single large unopened flower head of Pitcher's thistle, from two sites in Sleeping Bear Dunes National Lakeshore (Empire, Michigan [MI]): Good Harbor Bay ( $n=15$ per year) and Peterson Beach ( $n=15$ per year) on 7 June 1999 and 12 June 2000 (U.S. Fish and Wildlife Service Permit TE 009673, State of Michigan Permits 1086 and 1225, U.S. National Park Service Permits SLBE-1999/2000-154). Stems were re-cut and kept in water in a refrigerator overnight. The next day they were packed in plastic with moist paper towels and shipped in an insulated container (one-day delivery) to Cedar Point Biological Station, near field sites with naturalized populations of $R$. conicus in Nebraska. Branches of $C$. nutans, and, in 2000, branches of C. canescens as well, also were harvested at the same time from sites near the station in Nebraska (7 June 1999, 12 June 2000) to make sure that time since cutting was comparable among all species to be tested.

The day after shipping (9 June 1999, 14 June 2000), five branches were chosen randomly for no-choice tests in the laboratory. The remaining 25 branches were used in the choice tests, paired with branches of musk thistle (Carduus nutans spp. leiophyllus) with a similarly sized flower head ( $n=25$ in 1999, $n=20$ in 2000) as the main contrast, or with a similar branch from Platte thistle (Cirsium canescens) as a subsidiary contrast ( $n$ $=5$ in 2000). For choice tests, two flasks filled with nutrient solution, one containing a branch of Pitcher's thistle and the other containing one matched branch of the exotic $C$. nutans or alternative thistle species, were placed inside each of 30 insect cages $(30 \times 30 \times 30$ $\mathrm{cm} ; 0.5-\mathrm{mm}$ mesh). We added two mating pairs of $R$. conicus adults to each cage. Weevils had been collected during the week prior to the experiment from musk thistle (Lincoln County, NE) and Platte thistle (Arthur County, NE); these weevils were kept and allowed to mix freely in an insect cage in the laboratory. For nochoice tests, one flask with nutrient solution in a cage received one mating pair of $R$. conicus adults.

We recorded the number of $3-\mathrm{mm}^{2}$ feeding scars and the number of eggs laid on each head by examining plants every morning, afternoon, and evening in 1999 and every afternoon in 2000 , for the next $5 \mathrm{~d}$. We used the maximum number of egg cases observed by the end of the third day to quantify oviposition preference, for two reasons. First, most of the weevils (90\%) had laid eggs by the end of the second day; and, second, egg cases dropped off as they dried and a large number had dropped off by the end of the fourth day. The results of these tests were also compared directly to those from similar tests done with Platte thistle (Arnett and Louda 2002).

The response variables (area chewed, and number of $R$. conicus eggs oviposited) were transformed as necessary to reduce heterogeneity of variances. Area of feeding damage, based on the number of chewing scars per inflorescence, was square-root transformed. Counts, such as cumulative number of eggs laid per head, were $\ln (X+0.5)$-transformed. Area chewed and numbers of $R$. conicus eggs were analyzed using analysis of covariance (ANCOVA), with flower head diameter as the covariate (as in Arnett and Louda 2002). Flower head diameter was used as a covariate, since egg deposition could have varied with flower head size differences among replicates, even when heads within replicate trials were similar.

\section{Weevil colonization, development, and impact under garden conditions}

To supplement laboratory tests for host acceptance and preference, we used quantitative evidence on discovery, oviposition, development, and eclosion success by $R$. conicus on Pitcher's thistles spontaneously colonized by the weevil in 1999 on the Alberta Research Council grounds in Vegreville, Alberta, Canada. These plants were started from seed in 1997 and grown outside in pots, intermixed with other native and exotic Cirsium spp. being raised for use in host specificity tests of other thistle-feeding insects (McClay et al. 2000). The Pitcher's thistle plants $(n=13)$ were harvested at the end of the 1999 growing season and shipped to the University of Nebraska, Lincoln, NE, USA.

In the laboratory, we measured stem heights and counted the total number of flower heads initiated (>3.5 mm diameter) per stem. We then dissected each flower head and recorded evidence of weevil oviposition, feeding, and chamber development, as well as the number of larvae, pupae, and adults of $R$. conicus. Feeding scars could not be quantified accurately on the dried material. Voucher specimens were preserved. We also counted viable seed. These methods parallel those used in multiple field studies of thistles: Platte thistle (Louda and Potvin 1995, Louda and Arnett 2000, Rand and Louda 2004, Russell and Louda 2004; F. L. Russell and S. M. Louda, unpublished manuscript); wavyleaf thistle, Cirsium undulatum var. undulatum (Nutt.) Spreng. (Louda 2000a, F. L. Russell and S. M. Louda, unpublished manuscript); Tracy's thistle, C. undulatum var. tracyi (Rydb.) Welsh (Louda and O'Brien 2002); as well as Pitcher's thistle (Louda and McEachern 1995, Bevill et al. 1999). 
We analyzed the patterns of weevil attack, quantified as $R$. conicus development, damage, and occurrence within $C$. pitcheri flower heads, on plants in the garden in two ways. First, we used analysis of variance to test for differences in plant traits for stems with vs. without $R$. conicus, treating plant as a blocking variable. In addition to number of $R$. conicus per stem, the response variables were number of viable seeds per head per stem, number of flower heads per stem, mean stem height $(\mathrm{cm})$, mean diameter per head per stem $(\mathrm{mm})$, and mean of flowering success (final stage of development). Flowering stage was indexed, using: $1=$ small flower head bud ( $<12 \mathrm{~mm}), 2=$ large bud $(>12$ $\mathrm{mm}$, but no florets exerted), $3=$ partial flower (at least one floret exerted), $4=$ full flower $(>50 \%$ florets exerted and with color), $5=$ maturing seed (florets brown, dried, seeds undispersed), and $6=$ released $(>50 \%$ seeds dispersed), following Lamp and McCarty (1981, 1982). Less than $5 \%$ of the heads dissected had dispersed seed prior to collection and examination.

Counts were square-root transformed and measurements were $\ln (X+0.5)$-transformed when necessary to decrease heterogeneity of variances. Probabilities were corrected for multiple comparisons using the Bonferroni procedure (Systat; SPSS 2000). Second, we analyzed weevil response in relation to plant size (tall, $>25 \mathrm{~cm}$; short, $\leq 25 \mathrm{~cm}$ ) with number of $R$. conicus per stem as the response variable. We analyzed transformed counts, as described in the previous paragraph, using analysis of covariance to control for potential covariation in numbers and sizes of flower heads among stems within plants.

\section{Phenology and potential synchrony with resource availability}

Estimation of the likely oviposition period for $R$. conicus at latitudes that include Pitcher's thistle in protected habitat along the shores of Lake Michigan was a direct, linear interpolation by latitude between dates of observations of $R$. conicus activity to the north (A. S. McClay, unpublished data) and to the south (F. L. Russell and S. M. Louda, unpublished manuscript). This interpolative approach is consistent with the observed variation in $R$. conicus phenology in Europe (Aeschlimann 1999, Gassmann and Louda 2001). A likely mechanism for latitudinal variation in activity is temperature, since activity and fecundity of $R$. conicus respond to temperature variation (Smith et al. 1984, Smith and Kok 1987; F. L. Russell and S. M. Louda, unpublished manuscript). The interpolative method should lead to a conservative estimate of the likely temporal overlap of $R$. conicus with $C$. pitcheri, since lower temperatures in the $C$. pitcheri habitat along the lakeshore than predicted from inland continental sites available would be expected to delay $R$. conicus activity and so increase the likelihood of overlap with the documented flowering period of $C$. pitcheri. Female $R$. conicus were counted biweekly from early May through
June in 1997 to 2001 on Platte thistle in the Nebraska Sand Hills (Arapaho Prairie, 40 $56^{\prime} \mathrm{N}$ ), south of the National Lakeshores with $C$. pitcheri (Russell and Louda 2004; F. L. Russell and S. M. Louda, unpublished manuscript). To the north in Vegreville, Alberta (53 $30^{\prime}$ $\mathrm{N}), R$. conicus was observed on plants from the first week of June through the last week of July (A. S. McClay, unpublished data). These dates are consistent with other observations of dates of $R$. conicus activity in the eastern USA (Frick 1978, Surles and Kok 1978).

Estimation of the proportion of Pitcher's thistle flower heads that would be available during the calculated oviposition period for $R$. conicus used three years of field data on flowering phenology of Pitcher's thistle (S. M. Louda and A. K. McEachern, unpublished data). We quantified the number and timing of flower head production (1993-1995) in two U.S. national parks in which Pitcher's thistle is protected: four sites were at Indiana Dunes National Lakeshore (Porter, Indiana [IN]; $42^{\circ} 6^{\prime} \mathrm{N}$ ) and five sites were in Sleeping Bear Dunes National Lakeshore (Empire, MI; 44 $47^{\prime} \mathrm{N}$ ) (Louda and McEachern 1995; S. M. Louda and A. K. McEachern, unpublished data). In Indiana Dunes, the local sites were: Big Blowout Inner $(n=48,61,24$ plants in 1993, 1994, 1995, respectively), Big Blowout Outer ( $n=27,29,0$ plants), Howe's Beach ( $n=109$, 120, 24 plants), and West Beach ( $n=57,49,0$ plants). In Sleeping Bear Dunes, the local sites were (south to north): Platte River mouth ( $n=161,156,24$ plants), Peterson Beach ( $n=158,104,24$ plants), Aral Dunes ( $n=160,156,24$ plants), Sleeping Bear Plateau $(n=$ 104, 104, 24 plants), and Good Harbor Bay ( $n=103$, 94, 24 plants).

Early each season (7-15 May), we identified large rosettes that were likely to flower throughout the sand dune ecosystem at each site. Rosettes were numbered, mapped, and the number of flower heads recorded. We remeasured plants at $\sim 3$-wk intervals. Sampling dates over all years at Indiana Dunes were 6-14 May, 1-11 June, and 5-16 July; and at Sleeping Bear Dunes the dates were 28 May-7 June, 25-30 June, and 27-31 July. In our analysis, we averaged the total number of flower heads $(>3.5 \mathrm{~mm}$ diameter) available on each date at each site over the three years to determine the average pattern of flowering by locale. Curves of plant flower head development were fit statistically as third order polynomials using Systat 10.0 (SPSS 2000). To determine the overlap between the interpolated weevil oviposition period and the availability of Pitcher's thistle flower heads as resources for the weevil, we calculated the proportion of the total flower heads initiated per plant by the end of the calculated oviposition period.

\section{Demographic consequences}

A four-stage matrix model (Caswell 2001) for Pitcher's thistle was developed to assess whether the effects predicted at a particular life stage, seed production, 
would generate any corresponding demographic effects. The life-cycle diagram and stage transition matrix for $C$. pitcheri included four stages: seedling (with cotyledons), small juvenile (1-4 leaves), large juvenile ( $>4$ leaves), and flowering adult (Loveless 1984). All of the demographic parameters were extracted from Loveless (1984) for Sleeping Bear Dunes National Lakeshore, MI, except the proportion of seeds surviving predation by native insect floral herbivores, which came from Louda and McEachern (1995, and unpublished data). The value of $f$, the number of seedlings established per plant, includes the effect of $R$. conicus on seed production; it was calculated using alternative assumptions about attack rate with co-occurrence based on the laboratory test results.

\section{RESUlts}

\section{Host recognition and feeding}

Pitcher's thistle was accepted by $R$. conicus for feeding in both no-choice and choice tests (Fig. 1A). In nochoice tests, the mean area of $R$. conicus feeding scars per inflorescence averaged $59.6 \mathrm{~mm}^{2}$ (Fig. 1A). Average weevil feeding did not differ significantly between years: $62.0 \pm 9.86 \mathrm{~mm}^{2}$ (means $\pm 1 \mathrm{SE}$ ) in 1999 vs. $56.3 \pm 8.91 \mathrm{~mm}^{2}$ in 2000 (Table 1A). In choice tests with the coevolved exotic weed musk thistle $(C$. nutans), $R$. conicus showed no strong or consistent preference for musk thistle over the native Pitcher's thistle (Fig. 1A). Neither species $(P<0.75)$, nor year $(P<0.19)$ was a significant factor in the analysis of covariance (Table 1B). However, a significant species $\times$ year interaction $(P<0.01)$ suggested that the trend toward higher feeding on Pitcher's thistle in 1999 differed significantly from the trend toward higher feeding on musk thistle in 2000 (Fig. 1A).

The relative susceptibility of $C$. pitcheri, compared to its severely affected relative $C$. canescens, can be assessed both directly and indirectly. The direct measure is based on the small choice test conducted in 2000 $(n=5)$. In this test, the mean level of feeding on Pitcher's thistle $\left(28.5 \pm 10.44 \mathrm{~mm}^{2}\right)$ appeared to be lower than on the affected Platte thistle $(46.5 \pm 11.48$ $\mathrm{mm}^{2}$ ), but the difference in this small test was not statistically significant (ANCOVA, $F_{1,9}=1.480, P<0.26$, with head diameter as a covariate). The indirect measure is based on a comparison of $R$. conicus acceptance of Pitcher's thistle or of Platte thistle (Arnett and Louda 2002) relative to musk thistle in laboratory choice tests. In these tests, the area chewed by $R$. conicus on averaged $57.4 \pm 7.40 \mathrm{~mm}^{2}$ on Pitcher's thistle vs. 63.9 $\pm 13.97 \mathrm{~mm}^{2}$ on Platte thistle (Fig. 1A). These feeding responses by $R$. conicus to the two native species relative to musk thistle were not significantly different (Table 1C). Neither species, nor year was a significant factor in the variation observed. Together, these data strongly suggest that $R$. conicus feeding response to
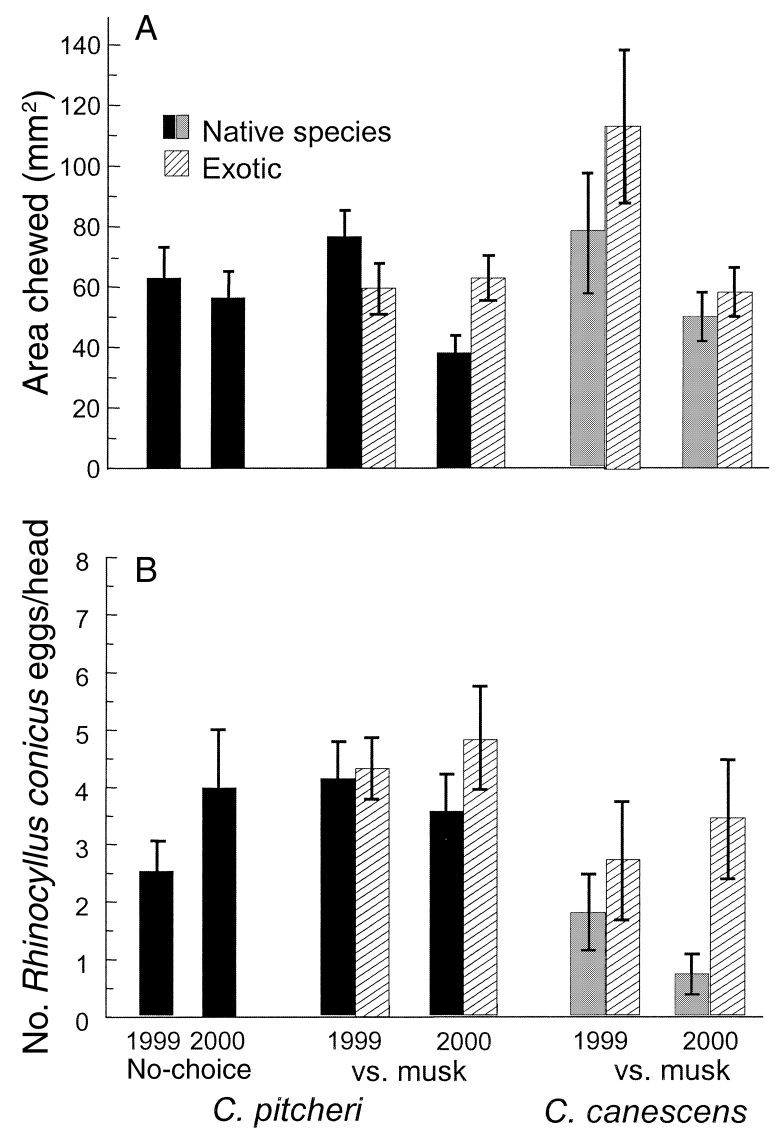

FIG. 1. Response of Rhinocyllus conicus to Cirsium pitcheri in laboratory feeding and oviposition tests in 1999 and 2000, under no-choice conditions (alone) vs. under choice conditions, with either the targeted exotic weed Carduus nutans (musk or nodding thistle) or its closely related congener Cirsium canescens (Platte thistle): (A) area of flower head and adjacent stem chewed by $R$. conicus over three days, and (B) maximum number of egg cases per flower head observed over each three-day test. The solid bars are native thistle types (black is the threatened Cirsium pitcheri, and gray is the closely related $C$. canescens), and the crosshatched bars are the exotic thistle, Carduus nutans. Shown are means \pm 1 SE.

Pitcher's thistle is comparable to its response to Platte thistle.

\section{Oviposition}

Pitcher's thistle was accepted for oviposition, in both no-choice and choice tests (Fig. 1B). In no-choice tests, there was a mean of $2.5 \pm 0.60$ eggs laid/inflorescence on Pitcher's thistle in 1999 and $4.0 \pm 0.97$ eggs laid/ inflorescence in 2000, exhibiting significant rather than chance oviposition acceptance in both years $(95 \%$ confidence intervals exclude zero) and no significant difference between years (Table 2A). In choice tests with its coevolved exotic host species, Carduus nutans, a trend toward higher preference for musk thistle (overall mean 4.8 vs. 3.8 eggs/head; Fig. 1B) was not significant (Table 2B). Neither species $(P<0.14)$ nor year $(P<$ 
TABLE 1. Feeding (area chewed) by Rhinocyllus conicus on Cirsium pitcheri; ANCOVA results with flower head diameter as the covariate.

\begin{tabular}{|c|c|c|c|c|c|}
\hline Factor & ss & df & MS & $F$ ratio & $P$ \\
\hline \multicolumn{6}{|c|}{ A) No-choice tests: $C$. pitcheri alone, 1999 vs. $2000\left(R^{2}=0.01\right)$} \\
\hline Year & 0.361 & 1 & 0.361 & 0.084 & 0.777 \\
\hline Head diameter & 0.044 & 1 & 0.044 & 0.010 & 0.921 \\
\hline Error & 55.995 & 13 & 4.307 & & \\
\hline \multicolumn{6}{|c|}{ B) Choice tests: $C$. pitcheri vs. $C$. nutans, 1999 vs. $2000\left(R^{2}=0.12\right)$} \\
\hline Species & 0.670 & 1 & 0.670 & 0.103 & 0.749 \\
\hline Year & 11.491 & 1 & 11.491 & 1.771 & 0.187 \\
\hline Species $\times$ year & 52.589 & 1 & 52.589 & 8.104 & 0.006 \\
\hline Head diameter & 4.546 & 1 & 4.546 & 0.701 & 0.405 \\
\hline Error & 551.592 & 85 & 6.489 & & \\
\hline \multicolumn{6}{|c|}{ C) Choice tests: $C$. pitcheri vs. $C$. canescens with musk thistle, $2000\left(R^{2}=0.03\right)$} \\
\hline Species & 0.104 & 1 & 0.104 & 0.007 & 0.931 \\
\hline Year & 1.860 & 1 & 1.860 & 0.133 & 0.716 \\
\hline Species $\times$ year & 16.707 & 1 & 16.707 & 1.196 & 0.279 \\
\hline Head diameter & 9.869 & 1 & 9.869 & 0.706 & 0.404 \\
\hline Error & 796.309 & 57 & 13.970 & & \\
\hline
\end{tabular}

$0.48)$, nor their interaction $(P<0.92)$ was significant in explaining the variation observed (Table $2 \mathrm{~B}$ ).

We also compared $R$. conicus oviposition response to Pitcher's thistle with its oviposition response to its more common relative Platte thistle. First, in the small, direct, choice test in 2000, we observed twice as many eggs oviposited on Pitcher's thistle $(2.5 \pm 1.26$ eggs/ head) as on Platte thistle (1.3 $\pm 0.56 \mathrm{eggs} / \mathrm{head})$ on average, but the difference was not statistically significant, likely reflecting our limited sample size $(n=5$; ANCOVA, with head diameter as the covariate, $F_{1,9}=$ $0.295, P<0.60)$. Second, in comparing choice tests for each of the native species against musk thistle, we unexpectedly found a significantly higher level of oviposition on Pitcher's thistle than on Platte thistle (4.1 $\pm 0.64 \mathrm{eggs} / \mathrm{head}$ vs. $1.8 \pm 0.66 \mathrm{eggs} / \mathrm{head}$ in 1999

TABle 2. Oviposition by Rhinocyllus conicus on Cirsium pitcheri in laboratory tests; ANCOVA results with head diameter as the covariate.

\begin{tabular}{|c|c|c|c|c|c|}
\hline Factor & SS & $\mathrm{df}$ & MS & $F$ ratio & $P$ \\
\hline \multicolumn{6}{|c|}{ A) No-choice test with $C$. pitcheri: 1999 vs. $2000\left(R^{2}=0.12\right)$} \\
\hline Year & 0.696 & 1 & 0.696 & 0.805 & 0.386 \\
\hline Head diameter & 0.095 & 1 & 0.095 & 0.110 & 0.745 \\
\hline Error & 11.232 & 13 & 0.864 & & \\
\hline \multicolumn{6}{|c|}{$\begin{array}{l}\text { B) Choice test: } C \text {. pitcheri vs. C. nutans: } 1999 \\
\text { and } 2000\left(R^{2}=0.03\right)\end{array}$} \\
\hline Species & 1.304 & 1 & 1.304 & 2.253 & 0.137 \\
\hline Year & 0.292 & 1 & 0.292 & 0.504 & 0.480 \\
\hline Species $\times$ year & 0.007 & 1 & 0.007 & 0.012 & 0.914 \\
\hline Head diameter & 0.357 & 1 & 0.357 & 0.617 & 0.434 \\
\hline Error & 49.214 & 85 & 0.579 & & \\
\hline \multicolumn{6}{|c|}{$\begin{array}{l}\text { C) Choice tests: } C \text {. pitcheri vs. on } C \text {. canescens in choice } \\
\text { tests with musk thistle, } 2000\left(R^{2}=0.13\right)\end{array}$} \\
\hline Year & 0.385 & 1 & 0.385 & 0.337 & 0.564 \\
\hline Species & 7.900 & 1 & 7.900 & 6.916 & 0.011 \\
\hline Year $\times$ species & 0.033 & 1 & 0.033 & 0.029 & 0.866 \\
\hline Head diameter & 0.003 & 1 & 0.003 & 0.003 & 0.959 \\
\hline Error & 65.110 & 57 & 1.142 & & \\
\hline
\end{tabular}

and $3.6 \pm 0.73$ vs. $0.7 \pm 0.29$ eggs/head in 2000) in the presence of musk thistle in the respective choice tests (Fig. 1B). No significant effect of year, and no interaction between species and year occurred (Table 2C).

Finally, a meta-analysis of the three experiments in which data on $R$. conicus oviposition rates on Pitcher's thistle were available (no choice, choice with musk, choice with Platte) showed no effect of experiment on oviposition rate (ANOVA, $F_{5,61}=0.734, P \leq 0.60$ ). Thus, Pitcher's thistle was as acceptable an oviposition host for $R$. conicus as its coevolved targeted species, $C$. nutans, and seemingly even more preferred for oviposition than its more common, affected relative, Platte thistle.

\section{Development}

Successful larval growth and pupal development to eclosion and emergence occurred on adventitiously colonized two-year-old flowering Pitcher's thistle plants in pots in the Alberta Research Council grounds in Vegreville, Alberta, in 1999. We found a total of 107 $R$. conicus developed successfully from the 398 flower heads ( $\geq 3.5 \mathrm{~mm}$ diameter) on 125 stems of the 13 potted Pitcher's thistle plants grown from seed. Nine of the 13 plants $(69.2 \%)$ were colonized, and 52 of the 125 stems (41.6\%), as well as 137 of the 398 flower heads $(34.5 \%)$, had evidence of $R$. conicus oviposition and development. There was an average of 1.0 overall and $2.1 R$. conicus per plant stem for attacked stems only (Fig. 2A). These data provide additional evidence of both host recognition and oviposition acceptance of Pitcher's thistle by $R$. conicus, and expand it to more natural outdoor conditions.

The data collected were sufficient to quantify the rates of spontaneous oviposition and successful development in relation to plant traits, as well as the effect of $R$. conicus on seed production by Pitcher's thistle 

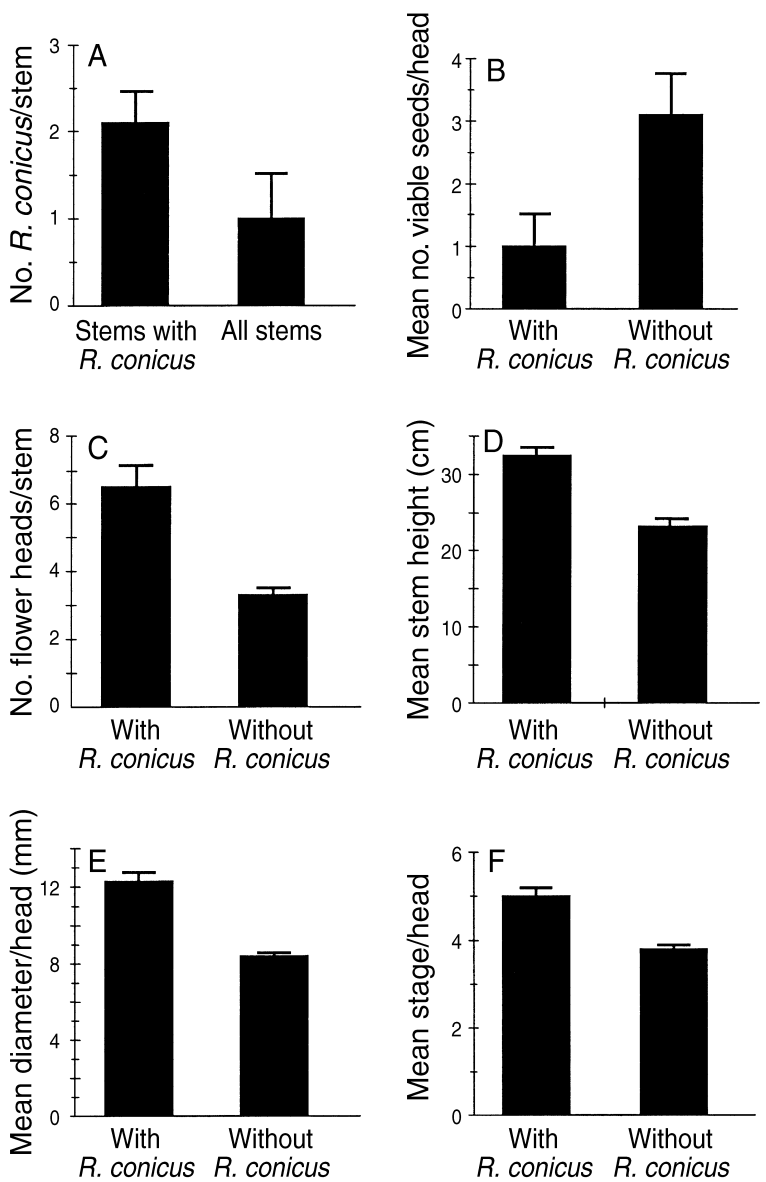

FIG. 2. Contrast between Cirsium pitcheri plants with vs. without evidence of spontaneous colonization by Rhinocyllus conicus of potted plants in the Alberta Research Council grounds in Vegreville, Alberta, Canada ( $n=51$ vs. 74 stems and 81 vs. 272 flower heads, with vs. without internal evidence of $R$. conicus feeding and development, respectively): (A) number of $R$. conicus that developed on plants with evidence of colonization, (B) number of viable seeds per flower head with vs. without evidence of $R$. conicus, (C) number of flower heads on stems with vs. without $R$. conicus colonization, (D) stem height of stems with vs. without $R$. conicus, (E) flower head diameter for heads with vs. without evidence of use by R. conicus, and (F) stage of flower head development for flower heads attacked by vs. not attacked by $R$. conicus. Stages are categorized as: 1 , small bud ( $<15 \mathrm{~mm}$ diameter); 2 , large bud ( $>15 \mathrm{~mm}$ diameter, with no florets exerted); 3 , partial flower $(1<$ florets exerted $<25)$; 4 , full flower (florets past receptivity); and 6, releasing or dispersing seed (following Lamp and McCarty [1981] and Bevill et al. [1999]). Shown are means +1 SE.

in the garden context. Comparison of stems with vs. without $R$. conicus suggested plants with more flower heads (Fig. 2C) on taller stems (Fig. 2D) were most susceptible to colonization by $R$. conicus, as is also the case for Platte thistle (Rose et al. 2005). To verify the role of plant height, we analyzed $R$. conicus numbers on tall $(>25 \mathrm{~cm})$ vs. on shorter $(\leq 25 \mathrm{~cm}) C$. pitcheri stems. We found that weevil colonization of and successful development on Pitcher's thistle was signifi- cantly greater on the tall stems than on the short ones (Table 3B), especially as the number of heads per stem increased (interaction of stem height $\times$ number of heads, $P<0.001)$.

Colonization by $R$. conicus of Pitcher's thistle in the garden also varied significantly among plants (Table 3B). The plants colonized by $R$. conicus had more flower heads (ANCOVA, $F_{1,122}=24.370$, corrected $P<$ 0.01; Fig. 2C) on taller stems on average (ANCOVA, $F_{1,122}=41.335$, corrected $P<0.01$; Fig. 2D). In addition, the flower heads on which oviposition occurred were generally larger (ANCOVA, $F_{1,350}=81.147$, corrected $P<0.01$; Fig. 2E) and more phenologically advanced (ANCOVA, $F_{1,354}=22.247$, corrected $P<$ 0.01 ; Fig. $2 \mathrm{~F}$ ). The number of $R$. conicus per head of C. pitcheri (Table $3 \mathrm{~A}$ ) reflected a highly significant effect of flower head size (1 mm diameter classes), when flower head position and plant were taken into consideration $\left(R^{2}=0.95\right.$; Table $\left.3 \mathrm{~A}\right)$. This result is consistent with the fact that $75.9 \%$ of the $R$. conicus egg cases and $74.2 \%$ of the weevils that were observed occurred on or in the terminal heads of the main stem and of the first two branches. These first three heads comprised almost $50 \%$ of the average 6.5 heads/stembranch of $C$. pitcheri with $R$. conicus (Fig. 2C) in this study.

Colonization, feeding, and development by $R$. conicus resulted in a $67 \%$ decrease, from $3.1 \pm 0.66$ to $1.0 \pm 0.48$ viable seed produced/head by $C$. pitcheri in the garden context (Fig. 2B), a significant drop (Table 3C). Production of viable seed was related to mean flower head size (Fig. 2E, Table 3D) as well as plant size. Flower heads colonized by $R$. conicus averaged $12.3 \pm 0.39 \mathrm{~mm}$ in diameter, while the heads that were not colonized averaged $8.4 \pm 0.19 \mathrm{~mm}$. Stems bearing these flower heads averaged $32.4 \pm 1.09 \mathrm{~cm}$, whereas stems that were not colonized and bore the smaller heads averaged only $23.1 \pm 0.86 \mathrm{~cm}$ (Fig. 2E). The model that best predicted the production of viable seed by $C$. pitcheri heads included the highly significant effect of flower head size (diameter) and $R$. conicus presence (Table 3C). Also, addition of $R$. conicus to the flower head guild in the garden environment significantly reduced the slope of the line relating increase in viable seed with increase in flower head diameter (Fig. 3).

Thus, the largest, most vigorous plants, expected to contribute most to recruitment in the protected habitat, were the most vulnerable to $R$. conicus colonization and impact. Oviposition by $R$. conicus was greater on more vigorous plants, with vigor represented as stature (height) and flower head production and resource availability. Flower head resource availability was measured as greater number of flower heads per stem, larger sized heads, and earlier, upper flower heads on the taller plants. Significantly, the interaction with $R$. conicus led to lower production of viable seed by $C$. pitcheri. 
TABLE 3. Results of ANCOVA for Rhinocyllus conicus occurrence on Cirsium pitcheri in pots in the Agricultural Experiment Station garden, Vegreville, Ontario, Canada in 1999.

\begin{tabular}{|c|c|c|c|c|c|}
\hline Factor & SS & df & MS & $F$ ratio & $P$ \\
\hline \multicolumn{6}{|c|}{ A) No. $R$. conicus per $C$. pitcheri head with vs. without $R$. conicus $\left(R^{2}=0.95\right)$} \\
\hline Head diameter & 124.078 & 296 & 0.419 & 2.395 & 0.001 \\
\hline Plant & 0.081 & 1 & 0.081 & 0.466 & 0.499 \\
\hline Head position & 0.193 & 1 & 0.193 & 1.101 & 0.300 \\
\hline Error & 7.351 & 42 & 0.175 & & \\
\hline \multicolumn{6}{|c|}{ B) No. $R$. conicus per stem on $C$. pitcheri by stem height class $\left(R^{2}=0.72\right)$} \\
\hline Stem height class & 31.516 & 1 & 31.516 & 28.859 & 0.001 \\
\hline No. heads & 5.976 & 6 & 0.996 & 0.912 & 0.490 \\
\hline Stem height $\times$ heads & 48.302 & 5 & 9.660 & 8.846 & 0.001 \\
\hline Plant & 4.972 & 1 & 4.972 & 4.553 & 0.035 \\
\hline Error & 110.301 & 101 & 1.092 & & \\
\hline \multicolumn{6}{|c|}{ C) No. viable seeds per $C$. pitcheri head with vs. without $R$. conicus $\left(R^{2}=0.84\right)$} \\
\hline Rhinocyllus presence & 2166.302 & 1 & 2166.302 & 21.680 & 0.001 \\
\hline Head diameter & 5534.579 & 1 & 5534.579 & 55.389 & 0.001 \\
\hline Plant & 34.489 & 1 & 34.489 & 0.345 & 0.557 \\
\hline Error & 34872.617 & 349 & 99.922 & & \\
\hline
\end{tabular}

\section{Phenological overlap}

For the weevil, the likely activity and oviposition period in the Indiana Dunes and Sleeping Bear Dunes National Lakeshore Parks along Lake Michigan, interpolated between observed dates in latitudes to the south and north, occurred between early-to-middle May and middle-to-late July (Fig. 4A). Specifically, the expected oviposition period of $R$. conicus in the southern portion of $C$. pitcheri range, such as at Indiana Dunes National Lakeshore (Porter, IN), should be at least from the second week of May through the last week of June into the first week of July (Fig. 4A). In a more northern area, such as Sleeping Bear Dunes National Lakeshore (Empire, MI), the interpolation leads to a conservative expectation of oviposition from the third week of May

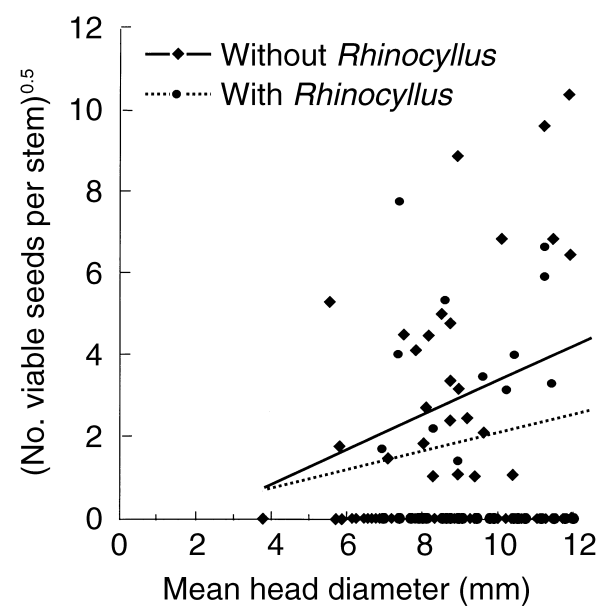

FIG. 3. Number of viable seeds per plant stem (squareroot transformed) for Cirsium pitcheri in relation to flower head diameter $(\mathrm{mm})$ for stems both with and without evidence of Rhinocyllus conicus colonization in the Alberta Research Council grounds in Vegreville, Alberta $(n=51$ and $n=74$ stems with and without $R$. conicus, respectively). through at least the first or second week of July (Fig. 4A). Cooler weather along the lakeshore could delay and lengthen the estimated activity period to the end of July.

For flower head resource availability, the field data on development of flower heads on C. pitcheri plants in situ available from those two National Lakeshore Parks suggest that the vast majority of its flower heads will be available and susceptible to oviposition during the expected $R$. conicus activity period. In the south, at four sites within or near the Indiana Dunes National Lakeshore, $>93 \%$ of the flower heads per plant, on average, were initiated before the end of the calculated $R$. conicus oviposition period there (end of June): $99.9 \%, 93.8 \%, 94.8 \%, 97.0 \%$ at the sites BBI, BBO, HWE, and WBE, respectively, from east to west within the park (Fig. 4B). These heads included all of the upper, larger flower heads that have the highest probability of setting viable seed (S. M. Louda and A. K. McEachern, unpublished data), such as those most damaged by R. conicus in Alberta (Table 3, Fig. 4). In the northern part of lower Michigan State, at five sites within the Sleeping Bear Dunes National Lakeshore, from $78 \%$ to $90 \%$ of all flower heads per plant at the park were initiated on average before the end of the conservatively calculated $R$. conicus oviposition period there (second to third week of July): $90.5 \%, 80.6 \%$, $81.6 \%, 78.1 \%$, and $85.0 \%$ at the sites $\mathrm{GH}, \mathrm{SBP}, \mathrm{AD}$, $\mathrm{PB}$, and PR, respectively, from north to south within the park (Fig. 4C). This number also included the larger, usually more successful flower heads (S. M. Louda and A. K. McEachern, unpublished data). Extending the activity period there by one to two weeks would increase the portion of heads exposed on the order of $5 \%$, to $95.0 \%, 84.6 \%, 85.7 \%$, and $89.2 \%$ respectively.

\section{Demographic model}

A life-cycle diagram and $4 \times 4$ matrix model for Pitcher's thistle are shown in Fig. 5. Each arrow rep- 

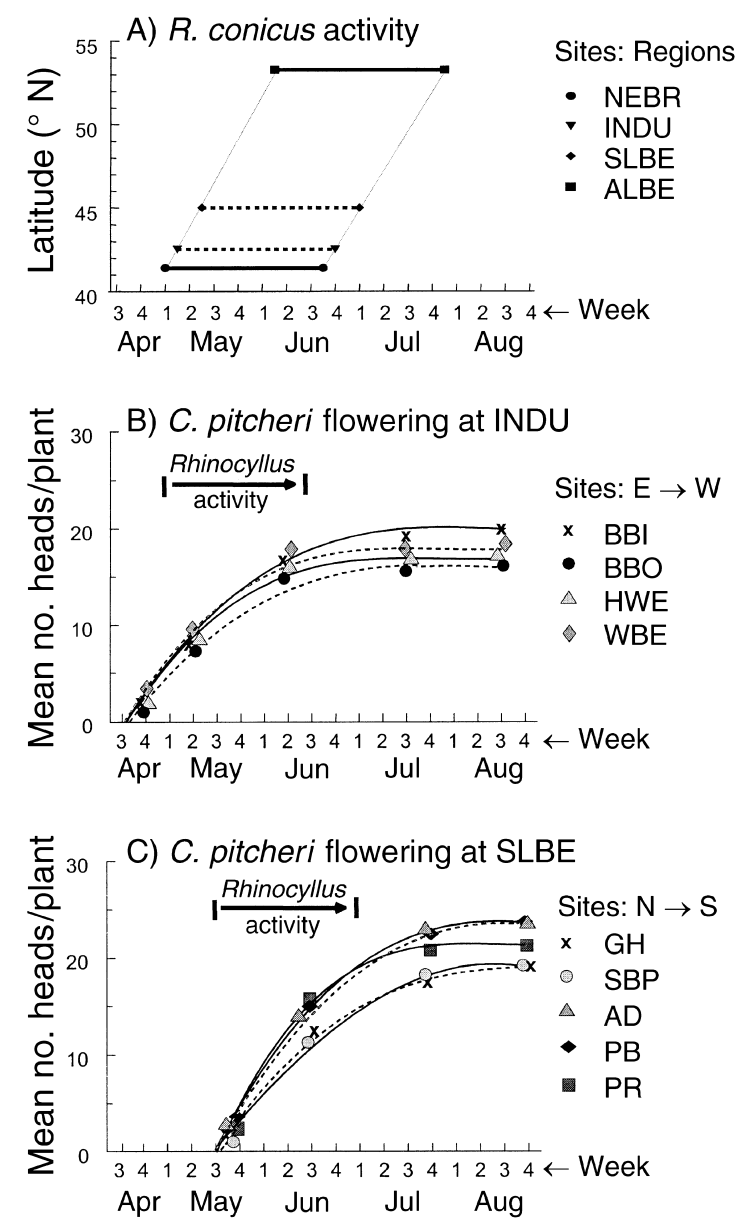

FIG. 4. (A) Phenology of Rhinocyllus conicus activity period with latitude. (B, C) Phenology of flowering by Cirsium pitcheri, averaged for 1993, 1994, and 1995, along southern Lake Michigan (B) at four sites in protected habitats of Indiana Dunes National Lakeshore in the south and (C) at five sites in protected habitats of Sleeping Bear Dunes National Lakeshore farther north. In (A), the latitudinal sites were (south to north): Arapaho Prairie Preserve, Arthur County, Nebraska, USA (NEBR; 40 $56^{\prime} \mathrm{N}$ ); Indiana Dunes National Lakeshore, Porter, Indiana, USA (INDU; $41^{\circ} 36^{\prime} \mathrm{N}$ ); Sleeping Bear Dunes National Lakeshore, Empire, Michigan, USA (SLBE; $44^{\circ} 47^{\prime} \mathrm{N}$ ); and Vegreville, Alberta, Canada (ALBE; $53^{\circ} 29^{\prime} \mathrm{N}$ ). The solid lines are reported activity periods; the dashed lines are interpolated activity periods in the parks where $R$. conicus does not occur yet. In panel (B), the expected $R$. conicus activity period is from panel (A), and the local sites were, from east to west: Big Blowout Inner (BBI; $n=48,61,24$ plants in 1993, 1994, 1995, respectively), Big Blowout Outer (BBO; $n=27,29$, 0 plants), Howe's Beach (HWE; $n=109,120,24$ plants), and West Beach (WBE; $n$ $=57,49,0$ plants). In panel (C), the expected $R$. conicus activity period is from panel (A), and the local sites were, from north to south: Good Harbor Bay $(\mathrm{GH} ; n=103,94,24$ plants), Sleeping Bear Plateau (SBP; $n=104,104,24$ plants), Aral Dunes (AD; $n=160,156,24$ plants), Peterson Beach (PB; $n=158,104,24$ plants), and Platte River mouth (PR; $n=161,156,24$ plants). Sampling dates across all years were 6-14 May, 1-11 June, and 5-16 July at Indiana Dunes, and 28 May-7 June, 25-30 June, and 27-31 July at Sleeping Bear Dunes. Curves were fit statistically as third-order polynomials (all $R^{2}>0.99$ ). resents the contribution of one individual in a stage to any other stage one year later. The parameter $f$ represents the number of new seedlings in the second year from one adult in the first year, incorporating seeds initiated, floral and seed predation, and seedling germination. In the presence of native floral predators only, the value of $f$ is 14.85 seedlings/adult. With $R$. conicus added to the native floral insects, and assuming conservatively that the relative proportion of seeds lost to both native insects and $R$. conicus scale as for Platte thistle, the value of $f$ is reduced $80.9 \%$, to 2.83 seedlings. Furthermore, if relative impact also includes the relative oviposition preferences shown for Pitcher's thistle vs. for Platte thistle in the choice tests with the targeted musk thistle above (Fig. 1B), then the value of $f$ becomes 1.32 seedlings ( $91.1 \%$ reduction).

With native predators only, the dominant eigenvalue for Pitcher's thistle is $\lambda=0.9897$; the population size is declining very slowly or is nearly steady. With the non-native weevil (Rhinocyllus conicus) added, the dominant eigenvalue declined $12 \%$ to $\lambda=0.8686$, assuming equal preference for Pitcher's thistle as for Platte thistle (C. canescens). Alternately, the dominant eigenvalue declined $15 \%$ to $\lambda=0.8395$, using the relatively higher preference of $R$. conicus for Pitcher's thistle observed in the laboratory oviposition tests (Fig. 1B). The cumulative consequences of these annual estimates of $\lambda$ can be compared by examining their effect on time to halve the population $\left(t_{0.5}\right)$. Under current conditions without $R$. conicus, the time to halve the population $\left(t_{0.5}\right)$ is 66.9 years. However, with $R$. conicus added to the floral insect herbivore guild, the estimated time to halve the population $\left(t_{0.5}\right)$ is only 4.9 years, assuming equal preference for Pitcher's thistle as for Platte thistle, or 4.0 years, assuming the relatively higher preference for Pitcher's thistle than Platte thistle observed in the laboratory tests.

\section{Discussion}

\section{Likelihood of ecological impacts}

Rhinocyllus conicus can recognize and use Pitcher's thistle as a potential feeding and oviposition host, in both laboratory tests and the garden environment. The "no-choice" laboratory tests showed significant feeding and oviposition. This finding suggests Pitcher's thistle is vulnerable to $R$. conicus in the absence of its targeted plant, an important finding since musk thistle does not occur within the U.S. National Parks with $C$. pitcheri in protected dune habitat (U.S. Fish and Wildlife Service 2002). Furthermore, in the "choice" situation with musk thistle (C. nutans), R. conicus unexpectedly showed no significant or consistent acceptance and oviposition preference for its coevolved weedy host plant relative to Pitcher's thistle. In addition, $C$. pitcheri was at least as acceptable to $R$. conicus as its close, severely impacted relative Platte thistle, 


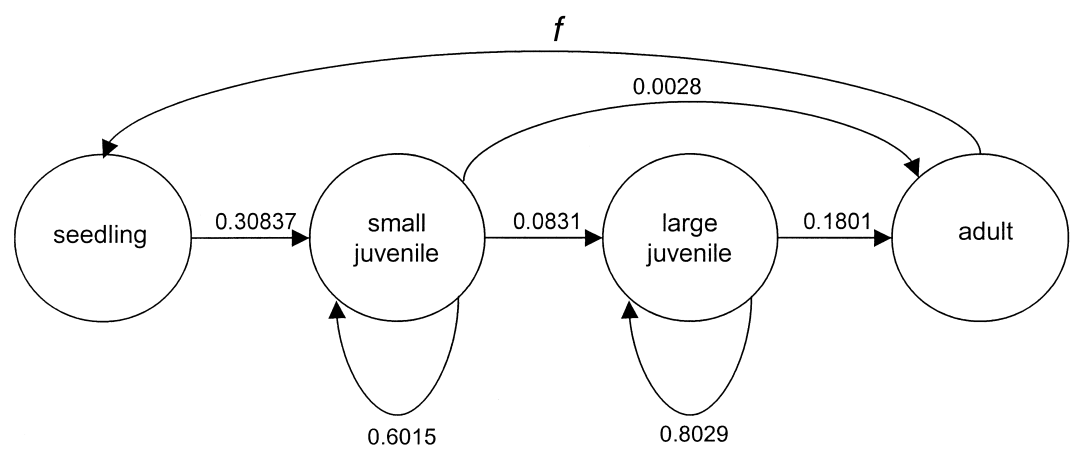

$$
\left(\begin{array}{cccc}
0 & 0 & 0 & f \\
0.3087 & 0.6015 & 0 & 0 \\
0 & 0.0831 & 0.8029 & 0 \\
0 & 0.0028 & 0.1801 & 0
\end{array}\right)
$$

$\begin{array}{clcc}\text { Herbivores } & \text { Rate of attack assumption } & f & \lambda \\ \text { Native insects only } & \text { Field data from 1993-1995 } & 14.85 & 0.9897 \\ \text { Natives + R. conicus } & \text { Rate observed on Platte thistle } & 2.83 & 0.8686 \\ \text { Natives + R. conicus } & \text { Relative rate from oviposition test } & 1.32 & 0.8395\end{array}$

FIG. 5. Life-cycle diagram and stage-transition matrix for Cirsium pitcheri at Sleeping Bear Dunes National Lakeshore, Michigan, USA, including four stages: seedling (with cotyledons), small juvenile (1-4 leaves), large juvenile ( $>4$ leaves), and flowering adult (Loveless 1984). All of the demographic parameters were extracted from Loveless (1984), except the proportion of seeds surviving predation by native insect floral herbivores (Louda and McEachern 1995, and unpublished data). The value of $f$, the number of seedlings established per adult plant, was calculated using alternative assumptions about attack rate with co-occurrence (assumptions detailed in Results: Demographic model).

suggesting a high probability of comparable or greater impact on Pitcher's thistle populations.

Also, R. conicus found and developed successfully on $C$. pitcheri, a prerequisite for the development of a population build up on Pitcher's thistle. Despite being rare in the area of Vegreville, Alberta (A. S. McClay, personal observation), $R$. conicus appeared in large numbers on potted $C$. pitcheri and other Cirsium spp. in the garden plot, suggesting that the weevil can efficiently locate and orient to suitable host plants from a considerable distance. The only other available hosts growing nearby are the exotic Cirsium arvense (L.) Scop. and the native $C$. flodmanii (Rydb.) Arthur. Rates of oviposition by $R$. conicus on $C$. arvense in the area appear to be very low, and the weevil has not yet been found attacking the later flowering $C$. flodmanii at Vegreville (A. S. McClay, personal observation). Development of $R$. conicus was complete on $C$. pitcheri, demonstrating that the weevil population can build up on this rare species once it is found.

Most of the Pitcher's thistle flower heads on plants within the protected habitats along Lake Michigan were initiated and available during the calculated $R$. conicus oviposition period. These results contrast to the only other quantitative study of the threat posed by $R$. conicus to a rare native thistle (C. hydrophilum var. vaseyi (Gray) J. T. Howell, Mt. Tamalpais thistle) in California (Herr 2000). In that study, low overlap between $R$. conicus and total flowering effort of this seep-dependent species was hypothesized to limit the weevil's numerical effect on the population. In the case of Pitcher's thistle, however, the phenological data provide strong, unequivocal evidence that the likely activity period of $R$. conicus will overlap the availability of the majority of flower heads produced by $C$. pitcheri. Depending upon specific site, at least $78-85 \%$ to $99 \%$ of all flower heads initiated by plants within the two protected parks would be exposed to $R$. conicus during its estimated oviposition period. This exposure rate is similar to that for Platte thistle (90-99\%), and so suggests that a similar strong negative impact on seed production and seedling recruitment of $C$. pitcheri is likely. These findings also support the hypothesis that quantification of likely temporal overlap can help predict the ecological interaction intensity of a biocontrol agent with a native species when host specificity tests show that the native species is within the larger host range. Indication of a temporal overlap also provides a basis for a po- 
tential long-term evolutionary increase in interaction intensity.

Finally, the demographic model shows that the projected loss of seed production is likely to have a major negative effect on population growth rate and persistence through its effect on seedling establishment. An annual decrease of $12-15 \%$ in population growth rate ( $\lambda$ ) from the current level of relative stability, observed in the model, has the potential of driving this already rare, federally listed species into decline. The cumulative effect, estimated as time to halve the population ( 66.9 to 4.0 or 4.9 years), is severe. Given the already limited range and population size of Pitcher's thistle (U.S. Fish and Wildlife Service 2002), such severe reductions in population growth rates also increase the likelihood and potential importance of other detrimental processes, such as Allee effects based on inbreeding depression or effects of pollen limitation, in small populations.

The results here provide direct evidence for the vulnerability of Pitcher's thistle to $R$. conicus at least of the same order of magnitude as its close, declining relative, Platte thistle (Louda and Arnett 2000, Rose et al. 2005; T. A. Rand and S. M. Louda, unpublished manuscript). We conclude that the data are sufficient to predict that $R$. conicus poses a major, serious risk to protected populations of $C$. pitcheri, an already exceptionally rare North American endemic species.

\section{Ecological parameters in the prediction of ecological risk}

Determining the direct ecological risk posed by an exotic insect herbivore species for native plant species necessarily includes at least two components. The most obvious one is a quantitative estimate of the dietary range of host plants, those likely to be recognized and potentially used by the insect. In weed projects, this physiological host range is well approximated by careful host specificity testing (Pemberton 2000a, Louda et al. 2003b). Contemporary evaluations of ecological risk rely primarily on this determination. Definition of this "physiological host range" is done by documenting patterns of host use in the indigenous environment and by testing the key components of host specificity (McEvoy 1996, Pemberton 2000a, Schaffner 2001, Louda et al. 2003a, $b$ ).

The basic set of parameters that define host specificity is adult host recognition, feeding acceptance and preference, oviposition acceptance and preference, plus successful larval and pupal development (DeBach and Rosen 1991, McEvoy 1996, Secord and Kareiva 1996). Adult insect behavior plus developmental success of the immature stages are considered the fundamental information needed to predict the potential for host range expansion by alien insects (McEvoy 1996, Marohasy 1998). Our laboratory and garden tests used the standard strategy to evaluate host range, and we found that Pitcher's thistle is unambiguously within the physiological host range of $R$. conicus.

The second, apparently less obvious, need is a quantitative estimate of the interaction intensity and magnitude of effect when feeding or oviposition on native species could occur. Assessment of the likely magnitude of interaction when a native species has been identified as a less preferred, or secondary, host species has lagged behind evaluations of host range. Expert opinion has been used to infer the likely magnitude of the ecological risk to populations of less preferred host plants in the field (Zwölfer and Harris 1984, McClay 1990, Blossey et al. 1994). However, expert opinion was not consistent with the magnitude of subsequent ecological impacts documented in the several cases for which quantitative data on nontarget effects are now available (Louda et al. 1997, 2003 b, Arnett and Louda 2002, Louda and O'Brien 2002).

It is not surprising, with hindsight, that the estimation of the magnitude of ecological risk to a native species identified as a potential host requires ecological data (Louda et al. 2003a, b). However, even though ecological data are acknowledged as potentially important (Follett and Duan 2000, Wajnberg et al. 2001), no such data are now required as a standard part of the ecological risk assessment protocols, even when a native species is identified as a less preferred, potential secondary host by the specificity tests. Although a petition to release a biological control insect should "present as clear a picture as possible of the long-term ecological consequences that could possibly result from the successful establishment of this agent in the North American environment" (USDA PPQ TAG guidelines; USDA 2001), no explicit guidance or criteria are proposed.

Quantification of phenological synchrony was hypothesized to be a critical parameter in the estimation of interaction intensity for less preferred native species that are accepted as secondary hosts. Temporal overlap between an herbivore and its plant resource has often been hypothesized to be critically important in plantherbivore interactions, including prediction of ecological host range and potential nontarget impact in biological control (Crawley 1997, Gassmann and Louda 2001, Louda et al. 2003b, Russell and Louda 2004; F. L. Russell and S. M. Louda, unpublished manuscript). Further, temporal overlap between potentially interacting species is considered a critical parameter for the prediction of ecological outcomes in general (Rathcke and Lacey 1985; F. L. Russell and S. M. Louda, unpublished manuscript). Our comparison of the phenologies of the insect and the rare plant indicate that significant phenological overlap is likely, providing the first quantitative estimate of likely ecological interaction intensity before contact between a native host plant and a biocontrol herbivore. These results demonstrate a novel, realistic way to use ecological information to develop a quantitative estimate of the likely interaction 
intensity for native species identified as possible host plants in host specificity testing. The outcome also provides data that support the suggestion that additional, ecological parameters are needed in risk assessment (Louda et al. 2003a, $b$ ). The main constraint on a reliance on the use of phenological overlap as a criterion for potential impact is that it is a measure of only contemporary, not evolutionary, overlap. Complete asynchrony would be required to predict no evolutionary potential for increased overlap, since even some phenological overlap would leave open the option for host switching.

Biological control practitioners have argued that phenological synchrony should be examined in prerelease assessments to increase the likelihood of weed control (Harris 1973, Goeden 1983). This study suggests that such assessment could be expanded to aid in the evaluation of the magnitude of potential nontarget side effects. Such information provides a quantitative way to better define exposure, as well as hazard, refining our ability to predict the risk of potentially significant demographic nontarget effects on populations of native species. Thus, we conclude that such information should be standard in assessments of magnitude of ecological risk for species within the potential host range of a biological control insect.

This study also demonstrated the utility of the experimental garden approach for evaluating plant traits that influence potential colonization, feeding, oviposition, and impact on performance of sensitive native species. This approach of using potted plants of the protected or rare species of interest, but done in an environment where the insect is established, provided critical insight on potential interaction intensity if overlap is established.

\section{Biological control and conservation of species in natural areas}

The study results are relevant also to the current interest in using biological control efforts against invasive exotic weeds in natural areas (Roush 1990, Quimby et al. 1991, Kauffman and Nechols 1992, Malecki and Blossey 1994, Office of Technology Assessment 1995, Pimentel 1995, Pimentel et al. 2000, Hoddle 2004). One motivation for advocates of more biological control efforts is the perception that the method, by definition, will restore natural enemy limitation, even in an entirely new community. It is also viewed as effective, cheap, and environmentally benign. However, success in biological control is elusive. For example, only $20 \%$ of weed projects show evidence of substantial decrease in weed density (Williamson and Fitter 1996), and another $20 \%$ were judged partially successful since the insect was established without evidence on weed limitation (Office of Technology Assessment 1995, Julien and Griffiths 1998). Furthermore, all successful introductions, whether effective or not, leave alien species in new environments (Simberloff 1986).

Also, recent studies have found unanticipated or higher than expected interaction intensities with nontarget native species by some insects used as biological control agents (Johnson and Stiling 1996, Louda et al. 1997, Boettner et al. 2000, Follett and Duan 2000, Stiling et al. 2000, Henneman and Memmott 2001, Wajnberg et al. 2001, Louda and O’Brien 2002). Unanticipated indirect and cascading ecological effects of biological control introductions on recipient native communities also have been reported recently (Callaway et al. 1999, Louda and Arnett 2000, Pearson et al. 2000). Thus, recent studies of nontarget effects (Follett and Duan 2000, Wajnberg et al. 2001, Louda et al. 2003b) challenge the automatic acceptance of this perception of safety in the conservation context.

Introduction of exotic species into new environments is a form of ecological engineering (Louda et al. $2003 a$ ). The relevance and applicability of ecological research on determinants of interaction intensities for biological control and invasive species management is clear (Crawley 1986, 1989, Follett and Duan 2000, Wajnberg et al. 2001, Shea and Chesson 2002). While perceived as "reestablishment of natural enemies" (Hoddle 2004), it is a more complex ecological manipulation, since the alien species are being introduced into new communities in new environments without their own natural enemies (Louda and Stiling 2004). The unexpected ecological outcomes, including unexpected interaction intensities, altered food webs, indirect and cascading effects, now known suggest the environment can alter expectations based on preference, and that serious, unexplored environmental costs can be associated with exotic species introductions, even when done with the best intentions.

Our results suggest that natural enemies that might affect sensitive and rare species, such as $C$. pitcheri, need to be tested for ecological host range, as well as physiological host range, and our study illustrates one way to expand testing in this direction. Furthermore, our results suggest that managers of natural areas should use great caution in releasing exotic insects for biological control when close relatives of target weeds (especially rare ones) exist in the preserve (Louda and Stiling 2004). We conclude that quantitative studies need to be done prior to release in any new habitat and that these studies should include ecological criteria for quantifying likely interactions and interaction intensities in native communities, especially in the conservation context.

\section{ACKNOWLEDGMENTS}

We thank Chad Andersen, Nate Brandt, Kayla Christensen Engel, Abigail Rogers Kula, and Jeannette Zimmer for help in the laboratory; Robert Hughes in the garden work; and Rob Bevill, Jennifer Fahey, Cheryl Murphy, Rod Otley, Julie Montgomery Wood, and Lynn Stanforth for help in the field over multiple years; Kathleen Keeler and Karen Rose for 
insightful comments on the manuscript; and M. Anwar Maun, University of Western Ontario, for providing Pitcher's thistle to A. S. McClay. We appreciate the encouragement of Lynn Loveless and Juliana Mulroy for our work on Pitcher's thistle, and the thorough demographic data gathered and published in detail in Lynn Loveless's dissertation. Partial support was provided by a grant from The National Science Foundation (DEB 92-21065); and logistical support from the University of Nebraska Cedar Point Biological Station and the National Park Service, at both Sleeping Bear Dunes and Indiana Dunes National Lakeshores, is gratefully acknowledged.

\section{Literature Cited}

Aeschlimann, J.-P. 1999. Specificity, and bionomics of southwestern Palaearctic biotypes of Rhinocyllus conicus Frölich (Col., Curculionidae), a biological control agent of $\mathrm{Pa}$ laearctic thistles (Asteraceae) accidentally introduced to Australia. Mitteilungen der Schweizerischen Entomologischen Gesellschaft 72:11-22.

Arnett, A. E., and S. M. Louda. 2002. Re-test of Rhinocyllus conicus host specificity, and the prediction of ecological risk in biological control. Biological Conservation 106: 251-257.

Benson, J., A. Pasqualte, R. G. Van Driesche, and J. Elkinton. 2003. Introduced braconid parasitoids and range reduction of a native butterfly in New England. Biological Control 28:197-213.

Bevill, R. L., S. M. Louda, and L. M. Stanforth. 1999. Protection from natural enemies in managing rare plant species. Conservation Biology 13:1323-1331.

Blossey, B., D. Schroeder, S. D. Hight, and R. A. Malecki. 1994. Host specificity and environmental impact of the weevil Hylobius transversovittatus, a biological control agent of purple loosestrife (Lythrum salicaria). Weed Science 42:128-133.

Boettner, G. H., J. S. Elkinton, and C. J. Boettner. 2000. Effects of a biological control introduction on three nontarget native species of Saturniid moths. Conservation Biology 14:1798-1806.

Boldt, P. E. 1997. Response of a Rhinocyllus researcher. Biocontrol News and Information 18:100N.

Bouskila, A., and D. T. Blumstein. 1992. Rules of thumb for predation hazard assessment: predictions from a dynamic model. American Naturalist 139:161-176.

Callaway, R. M., T. H. DeLuca, and W. M. Belliveau. 1999. Biological-control herbivores may increase competitive ability of the noxious weed Centaurea maculosa. Ecology 80:1196-1201.

Caswell, H. 2001. Matrix population models: construction, analysis, and interpretation. Second edition. Sinauer Associates, Sunderland, Massachusetts, USA.

Crawley, M. J. 1986. The population biology of invaders. Philosophical Transactions of the Royal Society of London, Series B 314:711-731.

Crawley, M. J. 1989. The success and failures of weed biocontrol using insects. Biocontrol News and Information 10: 213-223.

Crawley, M. 1997. Plant-herbivore dynamics. Pages 401474 in M. J. Crawley, editor. Plant ecology. Blackwell Science, Oxford, UK.

DeBach, P., and D. Rosen. 1991. Biological control by natural enemies. Second edition. Cambridge University Press, Cambridge, UK.

Delfosse, E. S. 2000. Biological control: important tool for managing invasive species. Agricultural Research 48:2

Easterling, M. R., S. P. Ellner, and P. M. Dixon. 2000. Sizespecific sensitivity: applying a new structured population model. Ecology 81:694-708.

Follett, P., and J. Duan. 2000. Nontarget effects of biological control. Kluwer Academic Publishers, Dortrecht, The Netherlands.
Frank, J. H. 1998. How risky is biological control? Comment. Ecology 79:1829-1834.

Frick, K. E. 1978. Biological control of thistles in the genus Carduus in the United States: a progress report. Science and Education Administration, USDA, Stoneville, Mississippi, USA.

Gassmann, A., and S. M. Louda. 2001. Rhinocyllus conicus: initial evaluation and subsequent ecological impacts in North America. Pages 147-183 in E. Wajnberg, J. K. Scott, and P. C. Quimby, editors. Evaluating indirect ecological effects of biological control. CABI Publishing, CABI International, Wallingford, Oxon, UK.

Goeden, R. D. 1983. Critique and revision of Harris' scoring system for selection of insect agents in biological control of weeds. Protection Ecology 5:287-301.

Goeden, R. D., and D. W. Ricker. 1986a. Phytophagous insect faunas of the two most common native Cirsium thistles, $C$. californicum and C. proteanum, in southern California. Annals of the Entomological Society of America 79:953-962.

Goeden, R. D., and D. W. Ricker. 1986b. Phytophagous insect faunas of two introduced Cirsium thistles, C. ochrocentrum and $C$. vulgare, in southern California. Annals of the Entomological Society of America 79:945-952.

Goeden, R. D., and D. W. Ricker. 1987a. Phytophagous insect faunas of native Cirsium thistles, $C$. mohavense, $C$. neomexicanum, and $C$. nidulum, in the Mojave Desert of southern California. Annals of the Entomological Society of America 80:161-175.

Goeden, R. D., and D. W. Ricker. 1987b. Phytophagous insect faunas of the native thistles, Cirsium brevistylum, Cirsium congdonii, Cirsium occidentale, and Cirsium tioganum in southern California. Annals of the Entomological Society of America 80:152-160.

Gonzalez, D., and F. E. Gilstrap. 1992. Foreign exploration: assessing and prioritizing natural enemies and consequences of preintroduction studies. Pages 53-70 in W. C. Kauffman and J. E. Nechols, editors. Selection criteria and ecological consequences of importing natural enemies. Entomological Society of America, Lanham, Maryland, USA.

Harris, P. 1973. The selection of effective agents for the biological control of weeds. Canadian Entomologist 105: 1495-1503.

Henneman, M. L., and J. Memmott. 2001. Infiltration of a Hawaiian community by introduced biological control agents. Science 293:1314-1316.

Herr, J. C. 2000. Evaluating non-target effects: the thistle story. Pages 12-17 in M. S. Hoddle, editor. Proceedings of the California Conference on Biological Control, July 1112, 2000. University of California, Riverside, California, USA.

Hoddle, M. S. 2004. Restoring balance: using exotics to control invasive exotic species. Conservation Biology 17:3849.

Hokkanen, H. M. T., and J. M. Lynch. 1995. Biological control: benefits and risks. Cambridge University Press, Cambridge, UK.

Howarth, F. G. 1991. Environmental impacts of classical biological control. Annual Review of Entomology 36:485509.

Johnson, D. M., and P. D. Stiling. 1996. Host specificity of Cactoblastis cactorum (Lepidoptera: Pyralidae), an exotic Opuntia-feeding moth, in Florida. Environmental Entomology 25:743-748.

Johnson, M. F., and H. H. Iltis. 1963. Preliminary reports on the flora of Wisconsin. Number 48. Compositae I. Composite family. Transactions of the Wisconsin Academy of Arts and Sciences 52:255-342.

Julien, M. H., and M. W. Griffiths, editors. 1998. Biological control of weeds, a world catalogue of agents and their target weeds. Fourth edition. CAB International, Wallingford, UK. 
Kauffman, W. C., and J. R. Nechols. 1992. Selection criteria and ecological consequences of importing natural enemies. Entomological Society of America, Lanham, Maryland, USA.

Keddy, C. J., and P. A. Keddy. 1984. Reproductive biology and habitat of Cirsium pitcheri. Michigan Botanist 23:5767.

Klein, M. 1991. Populationsbiologische: Untersuchungen an Rhinocyllus conicus Frölich (Coleoptera: Curculionidae): Allozym- und Morphometrieanalysen der in der biologischen Unkrauthekampfung eingesetzen Russelkaferart unter besonderer Berucksichtigung der Wirtspflanzensituation. Dissertation. University of Bayreuth, Germany.

Lamp, W. O., and M. K. McCarty. 1979. A preliminary study of seed predators of Platte thistle. Transactions of the Nebraska Academy of Sciences 7:71-74.

Lamp, W. O., and M. K. McCarty. 1981. Biology and ecology of Platte thistle (Cirsium canescens). Weed Science 29: 686-692.

Lamp, W. O., and M. K. McCarty. 1982. Predispersal seed predation of a native thistle, Cirsium canescens. Environmental Entomology 11:847-851.

Louda, S. M. 1994. Experimental evidence for insect impact on populations of short-lived, perennial plants, and its application in restoration ecology. Pages $118-138$ in M. L. Bowles and C. J. Whelan, editors. Restoration of endangered species. Cambridge University Press, Cambridge, UK.

Louda, S. M. 1998. Population growth of Rhinocyllus conicus (Coleoptera: Curculionidae) on two species of native thistles in prairie. Environmental Entomology 27:834-841.

Louda, S. M. 1999. Ecology of interactions needed in biological control practice and policy. Bulletin of the British Ecological Society 29:8-11.

Louda, S. M. 2000a. Negative ecological effects of the musk thistle biocontrol agent, Rhinocyllus conicus Fröl. Pages 215-243 in P. A. Follet and J. J. Duan, editors. Nontarget effects of biological control. Kluwer Academic Publishers, Boston, Massachusetts, USA.

Louda, S. M. 2000b. Rhinocyllus conicus: insights to improve predictability and minimize risk of biological control of weeds. Pages 187-193 in N. R. Spencer, editor. Proceedings, 10th International Symposium on the Biological Control of Weeds, 4-14 July 1999. Montana State University, Bozeman, Montana, USA

Louda, S. M., and A. E. Arnett. 2000. Predicting non-target ecological effects of biological control agents: evidence from Rhinocyllus conicus. Pages 551-567 in N. R. Spencer, editor. Proceedings of the 10th International Symposium on the Biological Control of Weeds, 4-14 July 1999. Montana State University, Bozeman, Montana, USA.

Louda, S. M., A. E. Arnett, T. A. Rand, and F. L. Russell. 2003a. Invasiveness of some biological control insects challenges adequacy of ecological risk assessment and regulation. Conservation Biology 17:1-11.

Louda, S. M., D. Kendall, J. Connor, and D. Simberloff. 1997. Ecological effects of an insect introduced for the biological control of weeds. Science 277:1088-1090.

Louda, S. M., and A. K. McEachern. 1995. Insect damage to inflorescences of the threatened dune thistle Cirsium pitcheri. Bulletin of the Ecological Society of America 76: 358.

Louda, S. M., and C. W. O'Brien. 2002. Unexpected ecological effects of distributing the exotic weevil, Larinus planus (F.), for the biological control of Canada thistle. Conservation Biology 16:717-727.

Louda, S. M., R. W. Pemberton, M. T. Johnson, and P. A. Follett. 2003b. Nontarget effects: the Achilles' heel of biological control? Retrospective analyses to reduce risk as- sociated with biocontrol introductions. Annual Review of Entomology 48:365-396.

Louda, S. M., and M. A. Potvin. 1995. Effect of inflorescence-feeding insects in the demography and lifetime fitness of a native plant. Ecology 76:229-245.

Louda, S. M., M. A. Potvin, and S. K. Collinge. 1990. Predispersal seed predation, postdispersal seed predation and competition in the recruitment of seedlings of a native thistle in sandhills prairie. American Midland Naturalist 124: $105-113$

Louda, S. M., M. A. Potvin, and S. K. Collinge. 1992. Predispersal seed predation in the limitation of native thistle. Pages 30-32 in S. B. J. Menken, J. H. Visser, and P. Harrewijn, editors. Insect-plant relationships. Kluwer Academic Publishers, Dordrecht, The Netherlands.

Louda, S. M., D. Simberloff, G. Boettner, J. Connor, D. Kendall, and A. E. Arnett. 1998. Insights from data on the nontarget effects of the flowerhead weevil. Biocontrol News and Information 26:70N-71N.

Louda, S. M., and P. Stiling. 2004. The double-edged sword of biological control in conservation and restoration. Conservation Biology 18:50-53.

Loveless, M. D. 1984. Population biology and genetic organization in Cirsium pitcheri, an endemic thistle. Dissertation. University of Kansas, Lawrence, Kansas, USA.

Loveless, M. D., and J. L. Hamrick. 1988. Genetic organization and evolutionary history in two North American species of Cirsium. Evolution 42:254-265.

Maddox, D. M., D. B. Joley, A. Mayfield, and B. E. MacKey. 1991. Impact of Bangasternus orientalis (Coleoptera: Curculionidae) on achene production of Centaurea solstitialis (Asterales: Asteraceae) at a low and high elevation site in California. Environmental Entomology 20:335-337.

Malecki, R., and B. Blossey. 1994. Insect biological weed control: an important and underutilized management tool for maintaining native plant communities threatened by exotic plant introductions. Pages 400-404 in Transactions, 59th North American Wildlife and Natural Resource Conference (1994). Wildlife Management Institute, Washington, D.C., USA.

Marohasy, J. 1998. The design and interpretation of hostspecificity tests for weed biological control with particular reference to insect behavior. Biocontrol News and Information 19: $13 \mathrm{~N}-20 \mathrm{~N}$

McCarty, M. K., W. O. Lamp, A. R. Martin, and F. W. Roeth. 1981. Introduced weevil helps control musk thistle. Farm, Ranch, and Home Quarterly 28(1):14-16.

McClay, A. S. 1990. The potential of Larinus planus (Coleoptera: Curculionidae), an accidentally-introduced insect in North America, for biological control of Cirsium arvense. Pages 173-179 in E. S. Delfosse, editor. Proceedings, 7th International Symposium on the Biological Control of Weeds, 6-11 March 1988. Instituto Sperimentale per la Patologia Vegetale, Rome, Italy.

McClay, A. S., R. A. Butts, and R. S. Bourchier. 2000. Assessing target and non-target effects of Lema cyanella released for control of Canada thistle. Pages 776-777 in N. R. Spencer, editor. Tenth International Symposium on Biological Control of Weeds. Montana State University, Bozeman, Montana.

McEachern, A. K. 1992. Disturbance dynamics of Pitcher's thistle (Cirsium pitcheri) populations in Great Lakes sand dune landscapes. Dissertation. University of Wisconsin, Madison, Wisconsin, USA.

McEvoy, P. B. 1996. Host specificity and biological pest control. BioScience 46:401-405.

McFadyen, R. E. C. 1998. Biological control of weeds. Annual Review of Entomology 43:369-393.

McKnight, B. N. 1993. Biological pollution: the control and impact of invasive exotic species. Indiana Academy of Science, Indianapolis, Illinois, USA. 
Myers, J. H., and D. R. Bazely. 2003. Ecology and control of introduced plants. Cambridge University Press, Cambridge, UK.

National Research Council. 2002. Predicting invasions of nonindigenous plants and plant pests. National Academy Press, Washington, D.C., USA.

Office of Technology Assessment. 1993. Harmful non-indigenous species in the United States, OTA-F-565 edition. United States Congress, U.S. Government Printing Office, Washington, D.C., USA.

Office of Technology Assessment. 1995. Biologically based technologies for pest control. United States Congress, U.S. Government Printing Office, Washington, D.C., USA.

Pearson, D. E., K. S. McKelvey, and L. F. Ruggiero. 2000. Non-target effects of an introduced biological control agent on deer mouse ecology. Oecologia (Berlin) 122:121-128.

Pemberton, R. W. 2000a. Predictable risk to native plants in weed biological control. Oecologia (Berlin) 125:489-494.

Pemberton, R. W. 2000b. Safety data crucial for biological control insect agents. Science 290:1896-1897.

Pimentel, D. 1995. Biotechnology: environmental impacts of introducing crops and biocontrol agents in North American agriculture. Pages 13-30 in H. M. T. Hokkanen and J. M. Lynch, editors. Biological control: benefits and risks. Cambridge University Press, Cambridge, UK.

Pimentel, D., L. Lach, R. Zuniga, and D. Morrison. 2000. Environmental and economic costs of nonindigenous species in the United States. BioScience 50:53-64.

Quimby, P. C., W. L. Bruckart, C. J. DeLoach, L. Knutson, and M. H. Ralphs. 1991. Biological control of rangeland weeds. Pages 84-102 in L. F. James, J. O. Evans, M. H. Ralphs, and R. D. Child, editors. Noxious range weeds. Westview Press, Boulder, Colorado, USA.

Rand, T. A., and S. M. Louda. 2004. Exotic weed invasion increases the susceptibility of native plants to attack by a biocontrol agent. Ecology 85:1548-1554.

Rathcke, B., and E. P. Lacey. 1985. Phenological patterns of terrestrial plants. Annual Review of Ecology and Systematics 16:179-214.

Rees, M., and K. E. Rose. 2002. Evolution of flowering strategies in Oenothera glazioviana: an integral projection model approach. Proceedings of the Royal Society of London, Series B 269:1509-1515.

Rees, N. E. 1982. Collecting, handling and releasing Rhinocyllus conicus, a biological control agent of musk thistle. Agriculture Research Service, USDA 579:1-7.

Rose, K. E., M. Rees, and S. M. Louda. 2005. Demographic and evolutionary impacts of native and invasive insect herbivores: a case study with Platte thistle, Cirsium canescens. Ecology 86:453-465.

Roush, R. T. 1990. Genetic variation in natural enemies: critical issues for colonization in biological control. Pages 263-287 in M. Mackauer, L. E. Ehler, and J. Roland, editors. Critical issues in biological control. Intercept, Andover, UK.

Russell, F. L., and S. M. Louda. 2004. Phenological synchrony affects interaction strength of an exotic weevil with Platte thistle, a native host plant. Oecologia 139:525-534.

Schaffner, U. 2001. Host range testing of insects for biological weed control: how can it be better interpreted? BioScience 51:951-959.

Secord, D., and P. Kareiva. 1996. Perils and pitfalls in the host specificity paradigm. BioScience 46:448-453.

Shea, K., and P. Chesson. 2002. Community ecology theory as a framework for biological invasions. Trends in Ecology and Evolution 17:170-176.

Simberloff, D. 1981. Community effects of introduced species. Pages 53-81 in M. H. Nitecki, editor. Biotic crises in ecological and evolutionary time. Academic Press, New York, New York, USA.
Simberloff, D. 1986. Introduced insects: a biogeographic and systematic perspective. Pages 3-26 in H. A. Mooney and J. A. Drake, editors. Ecology of biological invasions of North America and Hawaii. Springer-Verlag, New York, New York, USA.

Simberloff, D. 1992. Conservation of pristine habitats and unintended effects of biological control. Pages 103-117 in W. C. Kauffman and J. E. Nechols, editors. Selection criteria and ecological consequences of importing natural enemies. Entomological Society of America, Lanham, Maryland, USA.

Simberloff, D., and P. Stiling. 1996. How risky is biological control? Ecology 77:1965-1974.

Simberloff, D., and P. Stiling. 1998. How risky is biological control? Reply. Ecology 79:1834-1836.

Smith, L. M., II, and L. T. Kok. 1987. Influence of temperature on oviposition, quiescence, and mortality of Rhinocyllus conicus (Coleoptera: Curculionidae). Environmental Entomology 16:971-974.

Smith, L. M., II, F. W. Ravlin, L. T. Kok, and W. T. Mays. 1984. Seasonal model of the interaction between Rhinocyllus conicus (Coleoptera: Curculionidae) and its weed host, Carduus thoermeri (Campanulatae: Asteraceae). Environmental Entomology 13:1417-1426.

SPSS. 2000. Systat statistical package. Version 10.0. SPSS, Chicago, Illinois, USA.

Stiling, P., A. Rossi, and D. Gordon. 2000. The difficulties of single factor thinking in restoration: replanting a rare cactus in the Florida Keys. Biological Conservation 94: $327-333$.

Strong, D. R., and R. W. Pemberton. 2001. Food webs, risks of alien enemies, and reform of biological control. Pages 57-79 in E. Wajnberg, J. K. Scott, and P. C. Quimby, editors. Evaluating indirect ecological effects of biological control. CABI Publishing, CABI International, Wallingford, Oxon, UK.

Surles, W. W., and L. T. Kok. 1978. Carduus thistle seed destruction by Rhinocyllus conicus. Journal of the Weed Science Society of America 26:264-269.

Thomas, M. B., and A. J. Willis. 1998. Biocontrol: risky but necessary? Trends in Ecology and Evolution 13:325-329.

Turner, C. E. 1985. Conflicting interests and biological control of weeds. Pages 203-225 in E. S. Delfosse, editor. Proceedings of the Sixth International Symposium on $\mathrm{Bi}$ ological Control of Weeds. Agriculture Canada, Ottawa, Canada.

USDA. 2001. Reviewers manual for the technical advisory group for biological control agents of weeds. Guidelines for evaluating the safety of candidate biological control agents. First edition. USDA, Marketing and Regulary Programs, Animal and Plant Health Inspection Service, Plant Protection and Quarantine. PPQ document 12/2000-01, Frederick, Maryland, USA.

U.S. Fish and Wildlife Service. 2002. Pitcher's thistle (Cirsium pitcheri) recovery plan. Fish and Wildlife Reference Service, Bethesda, Maryland, and Fort Snelling, Michigan, USA.

Van Driesche, R., and T. S. Bellows. 1996. Biological control. Chapman and Hall, New York, New York. USA.

Wajnberg, E., J. K. Scott, and P. C. Quimby. 2001. Evaluating indirect ecological effects of biological control. CABI Publishing, CABI International, Wallingford, Oxon, UK.

Williamson, M., and A. Fitter. 1996. The varying success of invaders. Ecology 77:1661-1666.

Zwölfer, H., and P. Harris. 1984. Biology and host specificity of Rhinocyllus conicus (Froel.) (Col., Curculionidae), a successful agent for biocontrol of the thistle, Carduus nutans L. Zeitschrift der Angewandte Entomologie 97:36-62.

Zwölfer, H., and M. Preiss. 1983. Host selection and oviposition behaviour in west-European ecotypes of Rhinocyllus conicus Froel. (Col.: Curculionidae). Zeitschrift der Angewandte Entomologie 95:113-122. 